\title{
PENGARUH MODEL PEMBELAJARAN KOOPERATIF TIPE RECIPROCAL TEACHING TERHADAP HASIL BELAJAR SISWA PADA MATERI LOGIKA DI SMA NEGERI 5 PADANGSIDIMPUAN Oleh:
}

\author{
Mutia Sari ${ }^{1}$, Yuni Efrina Harahap ${ }^{2}$ \\ e-mail: mutiasani89@gmail.com
}

\begin{abstract}
This study aims to see the influence of the use of cooperative learning model type reciprocal teaching on the learning outcomes of students of logic material in class $X$ of SMA Negeri 5 Padangsidimpuan. This study uses an experimental method with non-equivalent design (untreated control group design with pretest and posttest). The results of the data analysis requirements test obtained by both classes of samples were normally distributed and homogeneous. The t-test results of the learning results obtained are $t_{-}$(count) $=2.936>t_{-}$(table) $=2.016$, so that there is a rejection of $\mathrm{H} \_\mathrm{O}$ and acceptance of $\mathrm{Ha}$. This means that there is the effect of using the cooperative learning model type reciprocal teaching on student learning outcomes in the logic material at Padangsidimpuan 5 High School.
\end{abstract}

\section{Abstrak}

Penelitian ini bertujuan untuk melihat adanya pengaruh penggunaan model pembelajaran kooperatif tipe reciprocal teaching terhadap hasil belajar siswa materi logika di kelas X SMA Negeri 5 Padangsidimpuan. Penelitian ini menggunakan metode eksperimen dengan desain non ekuivalen (untreated control group design with pretest and posttest). Hasil uij persyaratan analisis data diperoleh kedua kelas sampel berdistribusi normal dan homogen. Hasil uji-t hasil belajar yang diperoleh yaitu sehingga terjadi

penolakan 0 dan penerimaan $\mathrm{Ha}$. Artinya terdapat pengaruh penggunaan model pembelajaran kooperatif tipe reciprocal teaching terhadap hasil belajar siswa pada materi logika di SMA Negeri 5 Padangsidimpuan.

Kata kunci: Recirocal Teaching, Hasil Belajar, Logika. 


\section{PENDAHULUAN}

Matematika merupakan alat bantu untuk menyederhanakan penyajian dan pemahaman masalah, dengan menggunakan bahasa matematika suatu masalah dapat menjadi lebih sederhana untuk disajikan, dianalisa, dan dipecahkan. Meskipun demikian, mutu matematika di Indonesia sampai sekarang ini masih sangat rendah. Dalam kenyataan yang ada sekarang, penguasaan matematika, baik oleh peserta didik sekolah dasar (SD) maupun peserta didik sekolah menengah (SMP dan SMA), selalu menjadi permasalahan besar.

Berdasarkan hasil observasi pada kelas X SMA Negeri 5 Padangsidimpuan diperoleh gambaran kondisi peserta didik saat proses pembelajaran berlangsung pada mata pelajaran Logika. Setelah melakukan observasi di seluruh kelas X, ternyata ditemukan fakta bahwa dalam proses pembelajaran, guru telah menggunakan model pembelajaran aktif dengan menggunakan metode ceramah dan Tanya jawab. Selain mengadakan observasi, diadakan juga wawancara dengan salah seorang guru matematika di kelas X. Ibu Lely Tasari salah seorang guru matematika di kelas X IPA mengatakan bahwa kesulitan tersebut karena peserta didik kurang mengerti maksud dari soal sehingga dalam mengerjakan soal tidak dilakukan dengan cara yang sistematis. Menurut beliau mata pelajaran yang masih sangat sulit diterima atau dipahami siswa kelas $X$ yaitu mata pelajaran logika ${ }^{1}$. Logika merupakan pelajaran matematika yang membutuhkan pemahaman konsep yang lebih. Oleh karena banyaknya rumus yang harus diingat oleh siswa mengharuskan siswa agar paham terlebih dahulu konsep-konsep pada logika. Sehingga bukan lagi menghafal rumus, akan tetapi rumus akan terbentuk melalui pemahaman tersebut.

Pada dasarnya pembelajaran aktif adalah suatu pembelajaran yang mengajak peserta didik untuk belajar secara aktif. Peserta didik diajak untuk turut serta dalam proses pembelajaran tidak hanya mental tetapi juga fisik. Inovasi pembelajaran merupakan sesuatu yang penting dan harus dimiliki atau dilakukan oleh guru. Hal ini disebabkan pembelajaran akan lebih hidup dan bermakna. Salah satu model pembelajaran yang aktif dan inovatif adalah model pembelajaran kooperatif tipe Reciprocal Teaching.

Model pembelajaran kooperatif tipe Reciprocal Teaching merupakan model pengajaran terbalik. Pengajaran terbalik adalah pendekatan konstruktivis yang berdasar pada prinsip-prinsip pembuatan/pengajuan pertanyaan, dimana kemampuan-kemampuan metakognitif diajarkan melalui pengajaran langsung dan

${ }^{1}$ Lely Tasari, Guru Kelas X IPA, Wawancara di SMAN 5 Padangsidimpuan, pada Kamis, 22 Juni 2017, pukul 11.30 WIB. 
pemodelan oleh guru untuk memperbaiki kinerja membaca siswa yang membaca pemahamannya rendah. ${ }^{2}$ Kemudian model pembelajaran ini berupa kegiatan mengajarkan materi kepada teman. ${ }^{3}$ Dimana dalam hal kegiatan pembelajarannya peserta didik sendiri lah yang berperan sebagai guru dan menjelaskan materi kepada teman-temannya.

Model pembelajaran ini menuntut keaktifan dari masing-masing peserta didik dalam pembelajaran sehingga peserta didik membaca dan memahami terlebih dahulu materi yang akan diajarkannya kepada teman-temannya. Rasa tanggung jawab yang tinggi bagi setiap peserta didik akan melatih mental dan fisiknya. Guru di sini hanya berperan sebagai scaffolding agar, peningkatan kemampuan peserta didik dalam memahami konsep dapat terarah dengan baik dan dapat meningkatkan hasil belajar peserta didik.

Berdasarkan uraian di atas, tentang permasalahan dalam pembelajaran matematika penulis terdorong untuk melakukan penelitian dengan judul "Pengaruh Model Pembelajaran Kooperatif Tipe Reciprocal Teaching Terhadap Hasil Belajar Siswa Materi Pokok Logika di SMA Negeri 5 Padangsidimpuan.

"The term teaching model refers to a particular to instruction that includes its goals, syntax, environment, and management system." Artinya istilah model pembelajaran mengarah pada suatu pendekatan pembelajaran tertentu termasuk tujuan, sintaks, lingkungan, dan sistem pengelolaannya. ${ }^{4}$ Model pembelajaran adalah suatu perencanaan atau suatu pola yang digunakan sebagai pedoman dalam merencanakan pembelajaran di kelas atau pembelajaran dalam tutorial dan untuk menentukan perangkat-perangkat pembelajaran. Istilah model pembelajaran mempunyai makna yang lebih luas daripada startegi, metode atau prosedur. Model pengajaran mempunyai empat cirri khusus yang tidak dimiliki oleh strategi, metode atau prosedur. Ciri-ciri tersebut ialah:

1. Rasional teoritis logis yang disusun oleh para pencipta atau pengembangnya;

\footnotetext{
173.

${ }^{2}$ Trianto, Mendesain Model Pembelajaran Inovatif-Progresif (Jakarta: Kencana, 2009), hlm.

${ }^{3}$ Aris Shoimin, 68 Model Pembelajaran Inovatif dalam Kurikulum 2013 (Yogyakarta: Arruzz Media, 2014), hlm. 153.
}

\footnotetext{
${ }^{4}$ Aris Shoimin, 68 Model Pembelajaran Inovatif dalam Kurikulum 2013 (Yogyakarta: Arruzz Media, 2014), hlm. 23.
} 
2. Landasan pemikiran tentang apa dan bagaimana siswa belajar (tujuan pembelajaran yang akan dicapai);

3. Tingkah laku mengajar yang perlu dipikirkan agar model tersebut dapat dilaksanakan dengan berhasil, dan lingkungan belajar yang diperlukan agar tujuan pembelajaran itu dapat tercapai. ${ }^{5}$

Berdasarkan uraian mengenai pengertian model pembelajaran di atas, dapat ditarik kesimpulan bahwa model pembelajaran adalah suatu pendekatan yang digunakan dalam kegiatan pembelajaran untuk mencapai tujuan belajar.

Salah satu dari model pembelajaran kooperatif yaitu Reciprocal Teaching (pengajaran terbalik) adalah model pembelajaran yang dapat meningkatkan hasil belajar siswa pada materi pokok logika. Model pembelajaran Reciprocal Teaching dikembangkan oleh Anna Marie Palinscar dan Ann Brown untuk mengajar siswa strategi-strategi kognitif serta untuk membantu peserta didik memahami bacaan. Reciprocal Teaching adalah suatu penyampaian materi ajar dengan melakukan guru menunjuk seorang siwa untuk menggantikan perannya sebagai guru yang bertindak sebagai pemimpin diskusi dalam kelompok, yang sasarannya adalah mengajarkan 4 strategi pemahaman pengaturan diri spesifik, yaitu perangkum, pengaju pertanyaan, pengklarifikasian, dan prediksi. Sedangkan guru beralih peran dalam kelompok sebagai motivator, mediator, pelatih, memberikan dukungan, umpan balik, serta semangat bagi siswa.

Salah satu dari model pembelajaran kooperatif yaitu Reciprocal Teaching adalah model pembelajaran yang dapat meningkatkan hasil belajar siswa pada materi logika.

Reciprocal Teaching adalah model pembelajaran berupa mangajarkan materi kepada teman. Model pembelajaran reciprocal teaching dikenal juga sebagai pengeajaran terbalik karena, pada model pembelajaran ini siswa berperan sebagai "guru" untuk menyampaikan materi kepada teman-tamannya. Sementara itu, guru lebih berperan sebagai model yang menjadi fasilitator dan pembimbing yang melakukan scaffolding. Scaffolding adalah bimbingan yang diberikan oleh orang yang lebih tahu kepada orang yang kurang tahu atau belum tahu. ${ }^{6}$

Konstructivisme (konstruktivisme) merupakan landasan berpikir (filosofi) pendekatan kontekstual, yaitu bahwa pengetahuan dibangun oleh manusia sedikit demi sedikit. Manusia harus mengkonstruksi pengetahuan itu dan memberi makna melalui pengalaman nyata.

${ }^{5}$ Trianto, Mendesain Model Pembelajaran Inovatif-Progresif (Jakarta: Kencana, 2009), hlm.

${ }^{6}$ Aris Shoimin, Op.cit, hlm. 153. 
Berdasarkan uraian tentang pengertian model pembelajaran reciprocal teaching di atas, dapat disimpulkan bahwa reciprocal teaching merupakan suatu model pembelajaran yang dirancang untuk memberikan manfaat agar tujuan pembelajaran tercapai dan memberikan keterampilan pada siswa dalam memahami apa yang dibaca didasarkan pada pengajuan pertanyaan.

Pada awal penerapan pengajaran terbalik guru memberitahukan akan memperkenalkan suatu pendekatan/strategi belajar, menjelaskan tujuan, manfaat, dan prosedurnya. Selanjutnya mengawali pemodelan dengan membaca satu paragraf suatu bacaan. Kemudian menjelaskan dan mengajarkan kegiatan-kegiatan yang harus dilakukan yaitu:

1. Memikirkan pertanyaan-pertanyaaan penting yang dapat diajukan perihal hal yang telah dibaca, berkenaan dengan wacan, dan memastikan bisa menjawabnya.

2. Membuat ikhtisar/rangkuman tentang informasi terpenting dari wacana.

3. Memprediksi/meramalkan apa yang mungkin akan dibahas selanjutnya; dan

4. Mencatat apabila ada hal-hal yang kurang jelas atau tidak masuk akal dari suatu bagian, selanjutnya memeriksa apakah kita bisa berhasil membuat hal-hal itu masuk akal.

Dalam tahap kelanjutan pelaksanannya pengajaran terbalik melalui prosedur harian sebagai berikut:

1. Disediakan teks bacaan sesuai materi yang hendak diselesaikan.

2. Dijelaskan bahwa pada segmen pertama guru bertindak sebagai guru (model).

3. Siswa diminta membaca dalam hati bagian teks yang ditetapkan. Untuk memudahkan mula-mula bekerja paragraf demi paragraf.

4. Jika siswa telah menyelesaikan bagian pertama.

5. Siswa diminta untuk memberikan komentar tentang pengajaran yang baru berlangsung dan mengenai bacaan.

6. Segmen berikutnya dilanjutkan dengan bagian bacaan/ paragraf berikutnya, dan dipilih satu siswa yang dapat berperan sebagai "guru-siswa".

7. Siswa dilatih/diarahkan berperan sebagai "guru-siswa" sepanjang kegiatan itu. Mendorong siswa lain untuk berperan serta dalam dialog, namun selalu memberi "guru-siswa" itu untuk kesempatan memimpin dialog. Memberikan banyak umpan baik dan pujian kepada "guru-siswa" untuk peran sertanya.

8. Pada hari-hari berikutnya, semakin lama guru mengurangi peran dalam dialog, sehingga "guru-siswa" dan siswa lain itu berinisiatif sendiri 
menangani kegiatan itu. Peran guru selanjutnya sebagai moderator, menjaga agar siswa tetap berada dalam jalur dan membantu mengatasi kesulitan. ${ }^{7}$

Menurut Palinscar reciprocal teaching mengandung empat strategi yaitu:

1. Question Generating (Membuat Pertanyaan). Dalam strategi ini, siswa diberi kesempatan untuk membuat pertanyaan terkait materi yang sedang dibahas. Pertanyaan tersebut diharapkan dapat mengungkap penguasaan konsep terhadap materi yang sedang dibahas kemudian menyampaikannyadi depan kelas.

2. Clarifying (Mengklarifikasi). Strategi clarifying ini merupakan kegiatan penting saat pembelajaran, terutama bagi siswa yang mempunyai kesulitan dalam memahami suatu materi. Siswa dapat bertanya kepada guru tentang konsep yang dirasa masih sulit atau belum bisa dipecahkan bersama kelompoknya. Siswa diberi kesempatan untuk bertanya tentang materi yang dianggap sulit kepada guru. Guru berusaha menjawab dengan memberi pertanyaan pancingan, kemudian guru mengadakan tanyajawab terkait materi yang dipelajari untuk mengetahui sejauh mana tingkat pemahaman konsep siswa. Selain itu, guru juga dapat mengklarifikasi konsep dengan memberikan pertanyaan kepada siswa.

3. Predicting (Memprediksi). Strategi ini merupakan strategi dimana siswa melakukan hipotesis atau perkiraan mengenai konsep apa yang akan didiskusikan selanjutnya oleh penyaji. Siswa mendapat soal latihan dari guru untuk dikerjakan secara individu. Soal ini memuat soal pengembangan dari materi yang akan dibahas, hal ini dimaksudkan agar siswa dapat memprediksi materi apa yang akan dibahas pada pertemuan selanjutnya.

4. Summarizing (merangkum/menyimpulkan). Dalam strategi ini terdapat kesempatan bagi siswa untuk mengidentifikasikan dan mengintegrasikan informasi-informasi yang terkandung dalam materi. Siswa diminta menyimpulkan materi yang telah dibahas. ${ }^{8}$

\footnotetext{
${ }^{7}$ Ibid., hlm. 175.

${ }^{8}$ Aris Shoimin, 68 Model Pembelajaran Inovatif dalam Kurikulum 2013 (Yogyakarta: Arruzz Media, 2014), hlm. 153.
} 
Kelebihan dan kekurangan model pembelajaran reciprocal teaching:

1. Kelebihan:

a. Mengembangkan kreativitas siswa.

b. Memupuk kerja sama antar siswa.

c. Siswa belajar dengan mengerti.

d. Karena belajar dengan mengerti, siswa tidak mudah lupa.

e. Siswa belajar dengan mandiri.

f. Siswa termotivasi untuk belajar.

g. Menumbuhkan bakat siswa terutama dalam berbicara dan mengembangkan sikap.

h. Siswa lebih memperhatikan pelajaran karena menghayati sendiri.

i. Memupuk keberanian berpendapat dan berbicara di depan kelas.

j. Melatih siswa untuk menganalisis masalah dan mengambil kesimpulan dalam waktu singkat.

k. Menumbuhkan sikap mengahargai guru karena siswa akan merasakan perasaan guru pada saat mengadakan pembelajaran terutama pada saat siswa ramai atau kurang memperhatikan.

I. Dapat digunakan untuk materi pelajaran yang banyak dan alokasi waktu yang terbatas.

2. Kekurangan:

a. Adanya kekurangsungguhan para siswa yang berperan sebagai guru menyebabkan tujuan tak tercapai.

b. Pendengar (siswa yang tak berperan) sering menertwakan tingkah laku siswa yang menjadi guru sehingga merusak suasana.

c. Kurangnya perhatian siswa kepada pelajaran dan hanya memerhatikan aktivitas siswa yang berperan sebagai guru membuat kesimpulan akhir sulit tercapai.

d. Butuh waktu yang lama.

e. Sangat sulit diterapkan jika pengetahuan siswa tentang materi prasyarat kurang.

f. Adakalanya siswa tidak mampu akan semakin tidak suka dengan pembelajaran tersebut.

g. Tidak mungkin seluruh siswa akan mendapat giliran untuk menjadi "guru-siswa". 9

\footnotetext{
${ }^{9}$ Ibid. hlm. 156-157.
} 
Hasil belajar secara etimologi terdiri dari dua kata yaitu hasil dan belajar. Hasil adalah sesuatu yang diperoleh dengan usaha sedangkan belajar adalah suatu perubahan dalam tingkah laku yang mengarah pada hal baik. ${ }^{10}$ Hasil belajar merupakan realisasi atau pemekaran dari kecakapan yang dimiliki seseorang. Menurut Nana Sudjana, hasil belajar adalah kemampuankemampuan yang dimiliki siswa setelah ia menerima pengalaman belajarnya. ${ }^{11}$ Hasil belajar dapat diartikan sebagai tingkat keberhasilan siswa dalam mempelajari materi pelajaran di sekolah yang dinyatakan dalam skor yang diperoleh dari hasil tes mengenal sejumlah materi pelajaran tertentu." Untuk mengetahui apakah hasil belajar yang dicapai telah sesuai dengan tujuan yang dikehendaki dapat diketahui melalui evaluasi.

Evaluasi merupakan proses penggunaan informasi untuk membuat pertimbangan seberapa efektif suatu program telah memenuhi kebutuhan siswa. ${ }^{12}$ Berdasarkan uraian tentang pengertian hasil belajar di atas, dapat ditarik kesimpulan bahwa hasil belajar siswa adalah kemampuan yang diperoleh anak setelah melaui kegiatan belajar. Karena belajar itu sendiri merupakan suatu proses dari seseorang yang berusaha untuk memperoleh suatu bentuk perubahan perilaku yang relatif menetap. Dalam kegiatan pembelajaran atau kegiatan instruksional, biasanya guru menetapkan tujuan belajar. Anak yang berhasil dalam belajar adalah yang berhasil mencapai tujuan-tujuan pembelajaran atau tujuan instruksional.

\section{METODE PENELITIAN}

Penelitian ini dilaksanakan di SMA Negeri 5 Padangsidimpuan yang terletak di Jl. Melati No. 90 Padangsidimpuan Selatan. Penelitian ini dilaksanakan pada semester genap tahun ajaran 2017/2018. Waktu yang ditetapkan ini merupakan proses pembelajaran semester genap kelas $X$ yang disesuaikan dengan silabus mata pelajaran yang membahas materi logika.

Dalam hal ini, penelitian eksperimen menguji tentang pengaruh suatu variabel terhadap variabel lainnya. Penelitian ini akan melihat sejauh mana

${ }^{10}$ M. Ngalim Purwanto, Psikologi Pendidikan (Bandung: PT Remaja Rosdakarya, 2011), hlm. 81.

${ }^{11}$ Nana Sudjana, Penilaian Hasil Proses Belajar Mengajar (Bandung: PT. Remaja Rosdakarya 1992), hlm. 22.

12 Ahmad, Susanto, Teori Belajar dan Pembelajaran di Sekolah Dasar (Jakarta: Kencana Prenadamedia Group, 2013), hlm, 5. 
pengaruh reciprocal teaching terhadap hasil belajar siswa pada materi logika. Desain eksperimen yang digunakan adalah non ekuivalen (untreated control group design with pretest and posttest). Sebab penelitian ini menggunakan uji coba pada dua kelompok dengan membandingkan hasil dari setiap kelompok yang terdiri dari kelas eksperimen dan kelas kontrol.

Tabel 1. Desain Penelitian

\begin{tabular}{|c|c|c|c|}
\hline Kelas & Pretest & Perlakuan & Posttest \\
\hline Eksperimen & $\mathrm{T}_{1}$ & $\mathrm{X}$ & $\mathrm{T}_{2}$ \\
\hline Kontrol & $\mathrm{T}_{1}$ & - & $\mathrm{T}_{2}$ \\
\hline
\end{tabular}

$\begin{array}{cl}\text { Keterangan: } \mathrm{T}_{1} & \text { : Nilai pretest } \\ \mathrm{T}_{2} & \text { : Nilai posttest } \\ \mathrm{X} & \text { : Diberikan perlakuan musik instrumental } \\ - & : \text { Tidak diberikan perlakuan musik instrumental }\end{array}$

Desain ini digunakan untuk mengetahui pengaruh reciprocal teaching terhadap hasil belajar siswa pada materi logika di SMA Negeri 5 Padangsidimpuan.

Dalam penelitian ini peneliti mengambil sampel sebanyak 50 siswa kelas $X$ SMA Negeri 5 Padangsidimpuan, yaitu X-1 dengan jumlah 25 siswa sebagai kelas kontrol dan kelas X-2 dengan jumlah 25 siswa sebagai kelas eksperimen yang diberi perlakuan pengaruh reciprocal teaching terhadap hasil belajar siswa.

Variabel dapat diartikan sebagai karakter yang diambil antara satu dengan bagian dalam judul. Variabel penelitian ini terdiri dua yaitu variabel independen (variabel $\mathrm{x}$ ) dan variabel dependen (variabel y). Berdasarkan judul penelitian ini yang menjadi variabel $x$ adalah model pembelajaran reciprocal teaching, sedangkan variabel y dalam penelitian ini adalah hasil belajar siswa.

Peneliti menyusun rencana pelaksanaan pembelajaran (RPP) yang akan digunakan peneliti sebagai acuan dalam pelaksanaan pembelajaran. RPP tersebut disusun sesuai dengan komponen-komponen yaitu kompetensi inti, kompetensi dasar, indikator, tujuan pembelajaran, materi pembelajaran, metode atau media pembelajaran, langkah-langkah pembelajaran dan penilaian. Sebelum RPP diterapkan peneliti memvalidasikan RPP tersebut kepada validator yaitu dosen dan guru matematika.

Dalam penelitian ini, tes yang akan digunakan peneliti adalah tes uraian (essay) dengan jumlah tes adalah 7 butir. Alasan peneliti menggunakan tes uraian adalah agar siswa memiliki peluang lebih untuk mencurahkan pengetahuannya 
dalam menjawab soal yang diberikan sesuai dengan pembelajaran yang diikuti dan tidak menutup kemungkinan dari pengalaman yang didapatkan dalam kehidupan sehari-hari.

\section{HASIL DAN PEMBAHASAN}

\section{Deskripsi Data}

Data yang digunakan untuk menggambarkan hasil belajar Matematika siswa pada materi sistem persamaan linear tiga variabel di kelas X SMA Negeri 5 Padangsidimpuan yakni instrumen tes yang digunakan pada saat pretest dan postest. Gambaran dari pretest dan postest menunjukkan hasil belajar matematika siswa pada ranah kemampuan kognitif siswa.

a. Deskripsi Data Nilai Awal (Pretest) Hasil Belajar Matematika Siswa pada Materi Logika di SMA Negeri 5 Padangsidimpuan Setelah dilakukan uji coba instrumen tes penelitian di kelas X-3 SMA Negeri

5 Padangsidimpuan, diperoleh 5 butir soal tergolong valid dan dilakukan tes awal kepada sampel penelitian yakni kelas X-1 sebelum diberikan perlakuan (treatment). Hal ini dilakukan untuk mengetahui kondisi awal kemampuan sampel penelitian.

Data dideskripsikan untuk memperoleh gambaran awal mengenai hasil belajar matematika siswa pada materi logika. Daftar distribusi frekuensi skor nilai pretest dapat dilihat pada tabel berikut. Perhitungan selengkapnya pada tabel:

Tabel 2. Data Preetest Materi Logika

\begin{tabular}{|c|c|c|c|c|c|c|c|}
\hline \multicolumn{4}{|c|}{ Kelas Eksperimen } & \multicolumn{4}{c|}{ Kelas Kontrol } \\
\hline No & $\begin{array}{c}\text { Interval } \\
\text { Kelas }\end{array}$ & $\begin{array}{c}\text { Frekuensi } \\
\text { Absolut }\end{array}$ & $\begin{array}{c}\text { Frekuensi } \\
\text { Relatif }\end{array}$ & No & $\begin{array}{c}\text { Interval } \\
\text { Kelas }\end{array}$ & $\begin{array}{c}\text { Frekuensi } \\
\text { Absolut }\end{array}$ & $\begin{array}{c}\text { Frekuensi } \\
\text { Relatif }\end{array}$ \\
\hline 1 & $43-49$ & 3 & $12 \%$ & 1 & $40-47$ & 3 & $12 \%$ \\
\hline 2 & $50-56$ & 2 & $8 \%$ & 2 & $48-55$ & 2 & $8 \%$ \\
\hline 3 & $57-63$ & 4 & $16 \%$ & 3 & $56-63$ & 4 & $16 \%$ \\
\hline 4 & $64-70$ & 5 & $20 \%$ & 4 & $64-71$ & 5 & $20 \%$ \\
\hline 5 & $71-77$ & 4 & $16 \%$ & 5 & $72-79$ & 5 & $20 \%$ \\
\hline 6 & $78-84$ & 7 & $28 \%$ & 6 & $80-87$ & 6 & $24 \%$ \\
\hline
\end{tabular}

Tabel 2. Daftar Nilai Statistik Skor Awal (Pretest) Materi Logika

\begin{tabular}{|c|c|c|c|}
\hline No. & Nilai & Kelas Eksperimen & Kelas Kontrol \\
\hline 1 & Skor Tertinggi & 83 & 83 \\
\hline 2 & Skor Terendah & 43 & 40 \\
\hline 3 & Rentang & 40 & 43 \\
\hline 4 & Banyak Kelas & 6 & 6 \\
\hline
\end{tabular}




\begin{tabular}{|c|c|c|c|}
\hline 5 & Panjang Kelas & 6 & 7 \\
\hline 6 & Mean & 67,2 & 67,16 \\
\hline 7 & Variansi & 166,9166 & 209,89 \\
\hline 8 & Standar Deviasi & 12,9196 & 14,4875 \\
\hline 9 & Modus & 84 & 86 \\
\hline 10 & Median & 82,6 & 86,4 \\
\hline
\end{tabular}

Berdasarkan tabel di atas, dapat dilihat bahwa mean merupakan ukuran pemusatan data. Sedangkan variansi dan standar deviasi adalah perhitungan untuk mencari seberapa besar nilai penyimpangan atau perbedaan yang timbul dari rata-rata yang diperoleh. Disimpulkan bahwa data nilai kelas eksperimen maka semakin homogen distribusinya dan jika semakin besar range nya maka semakin heterogen distribusinya.

b. Deskripsi Data Nilai Akhir (Postest) Hasil Belajar Matematika Siswa pada Materi Logika

Setelah peneliti mendapatkan data awal dari kelas X SMA Negeri 5 Padangsidimpuan, peneliti selanjutnya melakukan treatment (perlakuan) dengan menggunakan model pembelajaran reciprocal teaching pada saat pembelajaran logika, dalam hal ini membahas negasi, konjungsi, disjungsi, implikasi.

Tabel 3.

Daftar Distribusi Frekuensi Skor Nilai Akhir (Postest) pada Materi Logika

\begin{tabular}{|c|c|c|c|c|c|c|c|}
\hline \multicolumn{4}{|c|}{ Kelas Eksperimen } & \multicolumn{4}{c|}{ Kelas Kontrol } \\
\hline No & $\begin{array}{c}\text { Interval } \\
\text { Kelas }\end{array}$ & $\begin{array}{c}\text { Frekuensi } \\
\text { Absolut }\end{array}$ & $\begin{array}{c}\text { Frekuensi } \\
\text { Relatif }\end{array}$ & No & $\begin{array}{c}\text { Interval } \\
\text { Kelas }\end{array}$ & $\begin{array}{c}\text { Frekuensi } \\
\text { Absolut }\end{array}$ & $\begin{array}{c}\text { Frekuensi } \\
\text { Relatif }\end{array}$ \\
\hline 1 & $50-56$ & 2 & $8 \%$ & 1 & $50-56$ & 4 & $16 \%$ \\
\hline 2 & $57-63$ & 2 & $8 \%$ & 2 & $57-63$ & 2 & $8 \%$ \\
\hline 3 & $64-70$ & 4 & $16 \%$ & 3 & $64-70$ & 5 & $20 \%$ \\
\hline 4 & $71-77$ & 4 & $16 \%$ & 4 & $71-77$ & 6 & $24 \%$ \\
\hline 5 & $78-84$ & 8 & $32 \%$ & 5 & $78-84$ & 6 & $24 \%$ \\
\hline 6 & $85-91$ & 5 & $20 \%$ & 6 & $85-91$ & 2 & $8 \%$ \\
\hline
\end{tabular}

Tabel 4. Daftar Nilai Statistik Materi Logika

\begin{tabular}{|c|c|c|c|}
\hline Nomor & Nilai & $\begin{array}{c}\text { Kelas } \\
\text { Eksperimen }\end{array}$ & Kelas Kontrol \\
\hline 1 & Skor Tertinggi & 91 & 85 \\
\hline 2 & Skor Terendah & 50 & 50 \\
\hline 3 & Rentang & 41 & 35 \\
\hline
\end{tabular}


Pengaruh Model Pembelajaran .........Mutia Sari

\begin{tabular}{|c|c|c|c|}
\hline 4 & Banyak Kelas & 6 & 6 \\
\hline 5 & Panjang Kelas & 7 & 6 \\
\hline 6 & Mean & 76,52 & 70,72 \\
\hline 7 & Variansi & 155,6766 & 115,96 \\
\hline 8 & Standar Deviasi & 12,4770 & 10,7684 \\
\hline 9 & Modus & 81,4 & 79,2 \\
\hline 10 & Median & 79,5 & 78,3 \\
\hline
\end{tabular}

Berdasarkan hasil deskripsi pada tabel 4.2 di atas, dapat dilihat bahwa nilai hasil belajar matematika siswa pada materi logika setelah perlakuan di kelas eksperimen diperoleh rata-rata nilai kelas eksperimen76,52 dan rata-rata nilai kelas kontrol 70,72. Berdasarkan tabel di atas dapat dilihat bahwa mean merupakan ukuran pemusatan data. Sedangkan variansi dan standar deviasi adalah perhitungan untuk mencari sebaran data yang berguna untuk mencari seberapa besar nilai penyimpangan atau perbedaan dari rata-rata yang diperoleh.

Data yang dideskripsikan untuk memperoleh gambaran tentang pengaruh model reciprocal teaching terhadap hasil belajar siswa pada ranah kognitif. Berikut ini daftar distribusi frekuensi skor nilai postest. Perhitungan selengkapnya pada lampiran 14 dan 15 (kontrol dan eksperimen).

Kesimpulan rata-rata nilai preetest kelas eksperimen 67,2 dan kelas kontrol 67,16. Rata-rata nilai postes kelas eksperimen 76,52 dan kelas kontrol 70,72.

c. Uji Persyaratan

1) Uji Persyaratan Data Nilai Awal (Pretest)

a) Uji Normalitas

Uji normalitas adalah sebuah uji yang digunakan untuk mengetahui kenormalan pada kelas sampel penelitian dilakukan dengan rumus:

$$
=1
$$

Uji normalitas berguna untuk menentukan data yang telah dikumpulkan berdistribusi normal atau diambil dari populasi normal. Penggunaan normalitas pada beberapa kondisi lebih praktis, karena normalitas telah melewati perhitungan terlebih dahulu sehingga tahap penyelesaian soal menjadi lebih cepat. Data yang diuji kenormalannya adalah data hasil pretest. Kelas X-1 merupakan sampel penelitian, setelah dilakukan uji normalitas pada kelas kontrol diperoleh 
diperoleh $_{2}=7,815$. Sehingga jelas ${ }_{h} \quad 2<2$ sehingga hipotesis itu berasal dari distribusi normal $\left(\mathrm{H}_{0}=\right.$ data distribusi normal) diterima. Hal ini berarti, kelas sampel yang diambil oleh peneliti tersebut berdistribusi normal.

b) Uji Homogenitas

Uji homogenitas dilakukan untuk mengetahui apakah nilai data awal sampel mempunyai varians yang sama (homogen).

$\mathrm{H}_{0}$ :

$\mathrm{H}_{1}$ :

Dari perhitungan diperoleh:

Varians terbesar $=204,8066$

Varians terkecil $=182,3683$

$F_{\text {hitung }}=2,29$

$F_{\text {tabel }}=2,30$

Oleh karena $F_{\text {hitung }}<F_{\text {tabel }}$ maka $\mathrm{H}_{0}$ diterima, artinya kedua kelas dalam penelitian ini mempunyai variansi yang sama (homogen).

c) Uji Kesamaan Dua Rata-rata

Analisis data yang digunakan adalah uji-t untuk menguji hipotesis dengan menggunakan rumus:

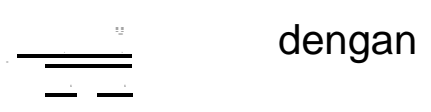

Berdasarkan hasil perhitungan uji kesamaan dua rata-rata diperoleh $\mathrm{S}=$ 13,913 , thitung $=-1,160$ dengan $\alpha=5 \%$ dan $\mathrm{dk}=\mathrm{N}-2=48$ diperoleh tabel $=$ 11,4914 . Karena thitung $<$ tabel maka $\mathrm{H}_{0}$ diterima artinya tidak ada perbedaan rata-rata antara kelas eksperimen dan kelas kontrol.

Berdasarkan analisis data di atas diperoleh kesimpulan bahwa sampel berdistribusi normal, homogen dan memiliki rata-rata awal yang sama. Hal ini berarti kedua kelas pada penelitian ini berawal dari kondisi yang sama.

2) Uji Persyaratan Data Nilai Akhir (Postest)

a) Uji Normalitas

Pengujian normalitas sama halnya dengan uji normalitas pretest. Berdasarkan perhitungan uji normalitas untuk kelas X-1 (kelas eksperimen) diperoleh $h \quad 2=3,7967$ dan untuk kelas X-2 (kelas kontrol) diperoleh $h \quad 2=2,8944$ dengan derajat kebebasan $\mathrm{dk}=(\mathrm{k}-3)=(6-3)=3$ dan taraf 
b) Uji Homogenitas

Uji homogenitas dilakukan untuk mengetahui apakah nilai data awal sampel mempunyai varians yang sama (homogen). Uji homogenitas digunakan pada uji parametris yang menilai perbedaan dua atau lebih kelompok.

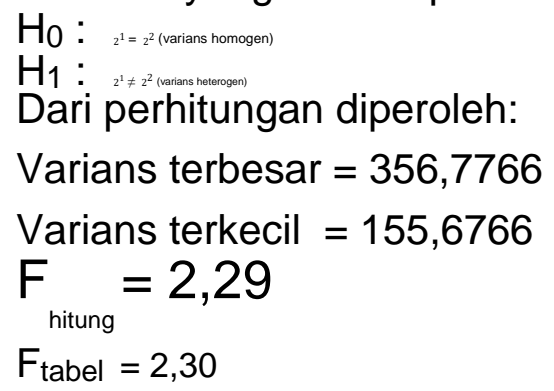

Oleh karena $F_{\text {hitung }}<F_{\text {tabel }}$ maka $\mathrm{H}_{0}$ diterima, artinya kedua kelas dalam penelitian ini mempunyai variansi yang sama (homogen).

c) Uji Perbedaan Dua Rata-rata

Analisis data yang digunakan adalah uji-t untuk menguji hipotesis dengan menggunakan rumus:

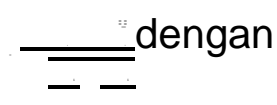

Berdasarkan hasil perhitungan uji kesamaan dua rata-rata diperoleh $\mathrm{S}=$ 16,0070 , thitung $=11,4914$ dengan $\alpha=5 \%$ dan $\mathrm{dk}=\mathrm{N}-2=48$, diperoleh tabel $=$ 2,0162. Karena thitung $>$ tabel maka $\mathrm{H}_{0}$ ditolak dan $\mathrm{H}_{a}$ diterima artinya ada perbedaan rata-rata antara kelas eksperimen dan kelas kontrol.

\section{Pengujian Hipotesis}

Dari uji persyaratan postest terlihat bahwa kedua kelas setelah perlakuan bersifat normal dan memiliki varians yang homogen. Maka untuk menguji hipotesis digunakan rumus uji-t pihak kanan, yaitu uji perbedaan dua rata-rata yang menentukan pengaruh penggunaan model reciprocal teaching. Syarat menggunakan uji-t karena uji-t termasuk kedalam golongan statistik parametrik, maka data penelitiannya harus distribusi normal, data berskala interval dan rasiodan homogenitas varians. Hipotesis yang diuji adalah: 
Artinya rata-rata hasil belajar siswa pada pokok bahasan logika yang menggunakan model reciprocal teaching tidak lebih baik dari rata-rata hasil belajar siswa tanpa menggunakan model reciprocal teaching.

Artinya rata-rata hasil belajar siswa pada pokok bahasan logika lebih baik dari rata-rata hasil belajar siswa tanpa menggunakan model reciprocal teaching. Dimana:

1 = rata-rata hasil belajar siswa kelas eksperimen $2=$ rata-rata hasil belajar siswa kelas kontrol

Pada uji persyaratan terlihat bahwa data nilai hasil belajar postest bersifat normal dan varians yang homogen, maka uji-t yang digunakan dalam uji hipotesisnya adalah:

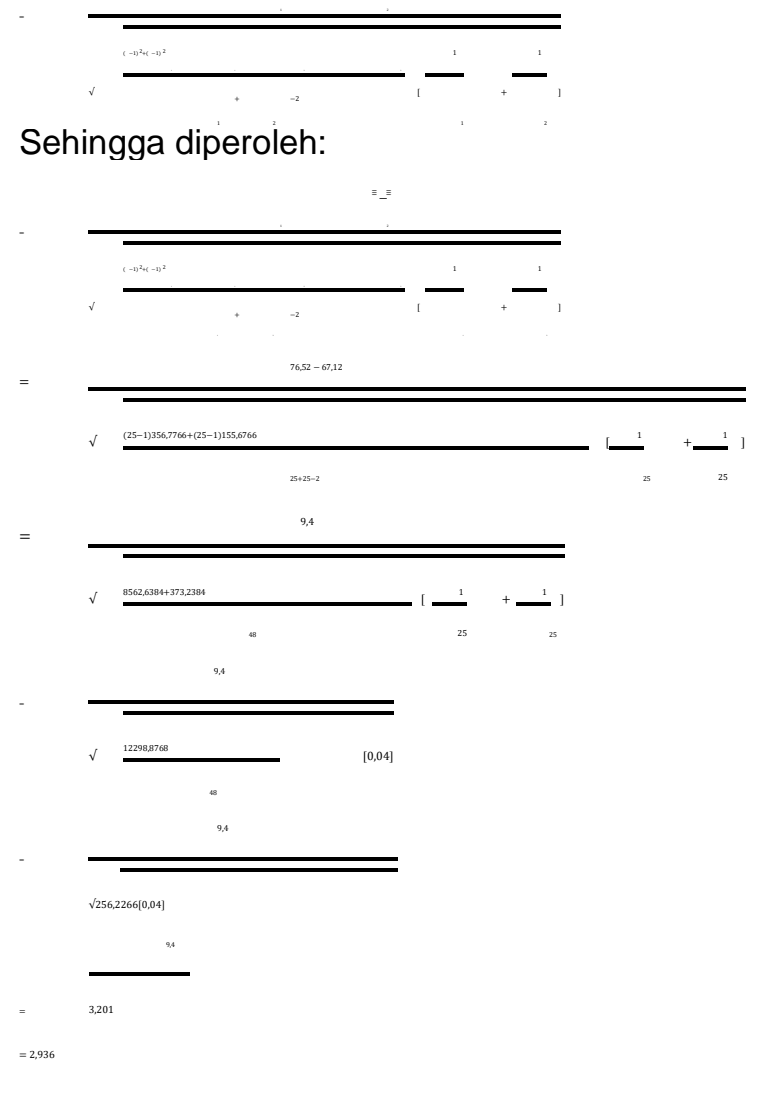

Kriteria pengujian adalah $\mathrm{H}_{0}$ diterima apabila $-t_{\text {tabel }}<$ thitung $<$ tabel dengan peluang $(1-\ldots$, dan $\mathrm{dk}=($ ${ }_{+-2)}$ dan tolak $\mathrm{H}_{0}$ jika mempunyai hargaharga lain. Dari perhitungan terlihat bahwa thitung $=2,936>$ tabel $=2,016$.

Kriteria Dari perhitungan di atas jelas terlihat penolakan $\mathrm{H}_{0}$ dan penerimaan $\mathrm{H}_{\mathrm{a}}$. Dengan demikian diterima, artinya rata-rata hasil belajar siswa 
pada pokok bahasan logika dengan menggunakan model reciprocal teaching lebih baik dari rata-rata hasil belajar siswa pada pokok bahasan logika tanpa menggunakan model reciprocal teaching. Uji-t merupakan salah satu jenis uji hipotesis yang sering digunakan dalam penelitian. Syarat menggunakan uji-t karena uji-t termasuk kedalam golongan statistik parametrik, maka data penelitiannya harus distribusi normal, data berskala interval dan rasiodan homogenitas varians.

Dari penerimaan $\mathrm{H}_{\mathrm{a}}$ dapat disimpulkan bahwa terdapat pengaruh yang signifikan antara penggunaan model reciprocal teaching terhadap hasil belajar siswa pada pokok bahasan logika kelas SMA Negeri 5 Padangsidimpuan.

\section{Pembahasan Hasil Penelitian}

Hasil penelitian ini menunjukkan bahwa kelas eksperimen dan kelas kontrol memiliki kondisi awal yang sama, setelah diadakan uji normalitas dan uji homogenitas menunjukkan bahwa kedua kelas yakni kelas eksperimen dan kelas kontrol tersebut berdistribusi normal dan homogen. Seterusnya dilakukan uji kesamaan dua rata-rata dan hasil kedua kelas tersebut mempunyai rata-rata yang sama.

Kelas eksperimen diberikan perlakuan, yaitu dengan menggunakan model pembelajaran reciprocal teaching pada pokok bahasan logika, sedangkan pada kelas kontrol tidak diberi perlakuan dengan model pembelajran reciprocal teaching. Proses pembelajaran pada kelas eksperimen diawali dengan menyampaikan tujuan dan memotivasi siswa, menyampaikan tujuan pelajaran yang ingin dicapai pada pelajaran logika, kemudian menjelaskan dengan singkat mengenai materi logika.

Sedangkan pada kelas kontrol dilaksanakan dengan menyampaikan tujuan dan memotivasi siswa, menyampaikan tujuan pelajaran yang ingin dicapai pada pelajaran logika, kemudian menjelaskan dengan singkat mengenai logika dan setelah itu, peserta didik diberi soal latihan untuk dikerjakan secara individu. Setelah dikenakan perlakuan pada kelas yang diteliti, kelas diberikan tes hasil belajar. Tes hasil belajar ini telah diujicobakan dan dilakukan analisis validitas, taraf kesukaran, daya pembeda soal dan reliabilitas soal. Dari perhitungan diperoleh kesimpulan bahwa tes hasil belajar tersebut valid dan reliabel.

Kelebihan penggunaan Reciprocal Teaching terhadap hasil belajar siswa adalah mempertajam seluruh keterampilan siswa berpikir visusal, dengan berintekrasi dan berdiskusi dengan kelompok akan melibatkan siswa secara aktif dalam belajar. 
Hasil dari tes kedua kelas tersebut dilakukan uji normalitas, uji homogenitas sebagai persyaratan dalam uji hipotesis penelitian. Dari perhitungan uji normalitas dan homogenitas, menunjukkan bahwa kedua kelas tersebut normal dan varians homogen. Dari perhitungan uji-t diperoleh hasil thitung $>$ ttabel $(2,936>2,016)$, menunjukkan bahwa rata-rata kelas eksperimen lebih baik dari kelas kontrol, artinya ada pengaruh yang signifikan penggunaan reciprocal teaching terhadap hasil belajar Matematika pokok logika pada siswa kelas X SMA Negeri Padangsidimpuan.

Rata-rata hasil belajar dengan menggunakan Model pembelajaran Reciprocal Teaching lebih baik, menurut peneliti hal ini disebabkan:

1. Reciprocal Teaching membantu peserta didik untuk saling bertukar pendapat dalam pembelajaran, sehingga membuat siswa lebih aktif dalam pembelajaran dan mampu memahami konsep pembelajaran dengan mudah.

2. Reciprocal Teaching juga juga membantu peserta didik melepaskan pola berpikir yang kaku sehingga dapat menyelesaikan soal-soal dengan lebih santai dan terbuka.

3. Reciprocal Teaching membantu siswa untuk berdiskusi dalam menyelesaikan masalah pembelajaran. Model pembelajaran reciprocal teaching dapat melatih siswa untuk lebih aktif sehingga siswa akan lebih memahami materi dan membantu siswa untuk mengkomunikasikan ideidenya dalam bentuk tulisan.

4. Penggunaan reciprocal teching di dalam kelas dapat membantu peserta didik agar mau mengungkapkan ide mereka dalam berdiskusi sehingga saling membantu dan saling bertukar pikiran.

\section{PENUTUP}

Dari penelitian yang dilakukan oleh peneliti, diperoleh kesimpulan bahwa ada pengaruh yang signifikan antara model pembelajaran reciprocal teaching terhadap hasil belajar siswa pada materi logika pada kelas X SMA Negeri 5 Padangsidimpuan. Hasil dari tes kedua kelas tersebut dilakukan uji normalitas, uji homogenitas sebagai persyaratan dalam uji hipotesis penelitian. Dari perhitungan uji normalitas dan homogenitas, menunjukkan bahwa kedua kelas tersebut normal dan varians homogen. Hal ini, ditunjukkan dari hasil uji hipotesis yang menyatakan bahwa ada pengaruh model pembelajaran kooperatif tipe reciprocal teaching terhadap hasil belajar siswa pada materi logika di SMA Negeri 5 Padangsidimpuan. 
DAFTAR PUSTAKA

Ahmad Susanto, Teori Belajar dan Pembelajaran di Sekolah Dasar, Jakarta: Kencana Prenadamedian Group, 2013.

Anas Sudjono, Pengantar Statistik Pendidikan, Jakarta: PT Raja Grafindo Persada, 2010.

Anas Sudjono, Pengantar Evaluasi Pendidikan, Jakarta: PT Raja Grafindo Persada, 2011.

Aris Shoimin, 68 Model Pembelajaran Inovatif dalam Kurikulum 2013, Yogyakarta: Ar-ruzz Media, 2014.

Dimyati dan Mudjiono, Belajar dan Pembelajaran, Jakarta: Rineka Cipta, 2006. Istarani dan Muhammad Ridwan, 50 Tipe, Strategi dan Teknik Pembelajaran Kooperatif, Medan: Media Persada, 2015.

Mardalis, Metode Penelitian, Jakarta: Bumi Aksara, 2003.

M. Ngalim Purwanto, Psikologi Pendidikan, Bandung: PT. Remaja Rosdakarya, 2011.

Nana Sudjana, Penilaian Hasil Proses Belajar Mengajar, Bandung: PT Remaja Rosdakarya, 2001.

Nana Syaodih Sukmadinata, Metode Penelitian Pendidikan, Bandung: PT Remaja Rosdakarya, 2010.

Purwanto, Evaluasi Hasil Belajar, Yogyakarta: Pustaka Pelajar, 2014.

Rangkuti Ahmad Nizar, Metode Penelitian, Bandung: Citapustaka Media, 2016. Rinaldi Munir, Matematika Diskrit, Bandung: Informatika Bandung, 2014.

S. Margono, Metode Penelitian Pendidikan, Jakarta: PT Rineka Cipta, 2004. Sugiyono, Metode Penelitian Pendidikan, Bandung: Alfabeta, 2014.

Suharsimi Arikunto, Metodologi Penelitian Suatu Pendidikan, Yogyakarta: Insan Madani, 2012.

Suharsimi Arikunto, Prosedur Penelitian Suatu Pendekatan Praktik, Jakarta: PT. Rineka Cipta, 2006.

Trianto, Mendesain Model Pembelajaran Inovatif-Progresif, Jakarta: Kencana 2009 